\title{
Paleo-landscapes of the Northern Patagonian Massif, Argentina
}

\author{
Emilia Y. Aguilera, Jorge Rabassa, and Eugenio Aragón
}

\begin{abstract}
The dominant geomorphological unit of the Northern Patagonian Massif landscape is a regional planation surface, eroded across the crystalline basement (plutonic and metamorphic rocks), eruptive rocks of the Gondwana cycle (Early to Middle Carboniferous), and Jurassic volcanic rocks.

The most important active climate during the genesis of this surface had a very significant role, developing intense chemical weathering extending to variable depths with the corresponding degradation of the rocky material exposed at the surface. Remnants of the weathering profiles, both outcropping and fossilized by burial, are identified and described. Such a particular mega-landform was developed in a cratonic environment, mainly as a product of deep weathering, and it is interpreted as a denuded surface, an etchplain formed by corrosion followed by erosion.

The analysis of the relationships between relief, saprolite, and rock cover throughout time suggests that the most important factor for the classification of the present landscape is the duration of exposure of the crystalline basement at the surface, from the end of the Paleozoic and during the entire Mesozoic. This conclusion has essential relevance for the evaluation of the effects of Mesozoic tectonics and the powerful weathering under certain climatic conditions.
\end{abstract}

\author{
E.Y. Aguilera ( $\square)$ \\ Facultad de Ciencias Naturales y Museo, Universidad Nacional de La Plata (UNLP), \\ Calles 122 y 60, 1900-La Plata, Argentina \\ DAIS (Dirección de Aplicación de Imágenes Satelitarias), Calle $7 \mathrm{~N}^{\circ} 1267-2^{\circ} \mathrm{P}$, \\ 1900-La Plata, Argentina \\ e-mail: eaguilera@ fcnym.unlp.edu.ar \\ J. Rabassa \\ Laboratorio de Geomorfología y Cuaternario, CADIC-CONICET, Ushuaia, Tierra del Fuego, \\ Argentina \\ Universidad Nacional de Tierra del Fuego, Ushuaia, Tierra del Fuego, Argentina \\ e-mail: jrabassa@gmail.com \\ E. Aragón \\ Centro de Investigaciones Geológicas (CIG), Calle $1 \mathrm{~N}^{\circ}$ 644, 1900, La Plata, Argentina
}


It is estimated that this paleosurface would have initiated its development towards the end of the Paleozoic, but later modifying also the Jurassic volcanic rocks that preceded the rifting processes that lead to the opening of the Southern Atlantic Ocean. Finally, the tectonic activity during the early Tertiary produced the exhumation of the planation surface, which was buried by its own regolith, reactivating erosion surfaces and small drainage basins. However, it is possible that some areas of the planation surface had never been covered by other rocks, other than its own overlying weathering products.

Our results suggest that the landscape features should not be assigned to Quaternary morphogenesis, but instead, they have evolved over a very long time, perhaps $100 \mathrm{Ma}$ or even more. These observations refer to Mesozoic times, and therefore the time scale used for the discussion of the geomorphology of the Northern Patagonian Massif should be enlarged to properly analyze the evolution of the ancient landscapes of this cratonic region.

This chapter contributes to the analysis of comparative studies of global geomorphology of cratonic areas, where planation surfaces record very long periods in which the speed of crustal deformation is highly compensated by planation processes.

Keywords Gondwana • Argentina • Northern Patagonian Massif • Etchplains • Granitic geomorphology

\section{Introduction}

The development and evolution of the landscape of the Northern Patagonian Massif is clearly related to the peculiar morpho-structural environment of this cratonic geological province and with the morpho-climatic systems from tropical to temperate and from humid to dry that were concomitant with the tectonic processes of uplift and structural deformation and later continental tear apart. Therefore, many of the observed landforms may have had their origins as early as $300 \mathrm{Ma}$, before the process of Gondwana breakup started.

The dominant mega-landform of this landscape is a very large planation surface, a geomorphological unit of regional magnitude associated with residual relief at various scales.

The different factors which determined the impact of ancient weathering rates, such as lithology, fracturing and jointing of the rocky blocks, their spatial variation, and climate and drainage, are very significant elements for this model of landscape evolution.

A varied morpho-structural context shapes up the landforms of the basement landscape, where the primary characteristics of the rocks such as mineralogy, texture, and structure determine their weathering and erosion, and their later transformation into regolith or saprolite (Aguilera et al. 2010; Aragón et al. 2005; Rabassa et al. 2014). In this chapter, the term "saprolite" is restricted to the 
whole volume of in situ weathered rock, whereas the term "regolith" applies to all overlying materials (including, loess, alluvium), that is, every mineral and rocky materials between fresh rock and fresh air, and it may involve also the saprolite, if it is still in situ (C. Ollier, 2012, personal communication). A fundamental aspect in the evolution of this landscape is the fracture systems in the rocks, both faults and joints, which fragment the granitic and metamorphic bodies generating appropriate ways of fluid circulation which selectively attack the minerals. The scale of observation of the rock fracturing includes those fractures of regional magnitude which articulate large landscape units, faults that divide plutons with relative block displacement, and joint systems generated by the emplacement of igneous bodies and micro-fractures.

The landforms determined by joint networks separate the basement rocks in parallelepipeds, affected by subaerial erosion which made progress through the joints, widening them and progressively rounding the edges of the blocks.

The variation of these factors that determine the weathering rate regulates the shape of the weathering front, which is generally markedly irregular and whose extension in depth does not necessarily preserve relationships with the surficial forms. During periods of climatic and tectonic stability, the weathering and denudation rates are almost balanced in the long term, equating the thickness and the depth advance of the weathering profile.

Modifications in the climatic régime or in the crustal uplift may change this dynamic equilibrium state, increasing erosion rates. The adjustments of the geomorphological systems have strong incidence in the stability of the weathering mantle, which may be partially or completely mobilized.

\section{Location of the Studied Areas}

The Northern Patagonian Massif, also known as the Somuncurá Massif (Fig. 1), is located in the provinces of Río Negro and Chubut, Patagonia, Argentina, with a minor extension into the province of Neuquén, where it is locally known as the Sañicó Block. It is included in the geographical region known as extraAndean Patagonia, with a prevailing tableland relief, with low ranges and sierras, depressions, hollows, and very broad terraced fluvial valleys, with a dominant westeast direction and carved by allochthonous streams with sources in the Northern Patagonian Andes.

The climate is semiarid to arid and cold, with strong winds coming from the west. The aridity of the present climate is a consequence of the Late Cenozoic uplift of the Patagonian Andes, which formed a barrier in the pathway of the humid winds coming from the Southern Pacific Ocean. The principal vegetation formation is the steppe, due to the scarcity of precipitation.

Three areas of the Massif are analyzed in this chapter: (a) one is located in the province of Río Negro, between $67^{\circ} 30^{\prime}$ and $70^{\circ} 30^{\prime}$ west longitude and $40^{\circ} 00^{\prime}$ and $42^{\circ} 00^{\prime}$ south latitude; (b) another is found in the province of Chubut between the 
Fig. 1 Regional location of Patagonia, Argentina, showing the Northern Patagonian Massif and the geotectonic setting

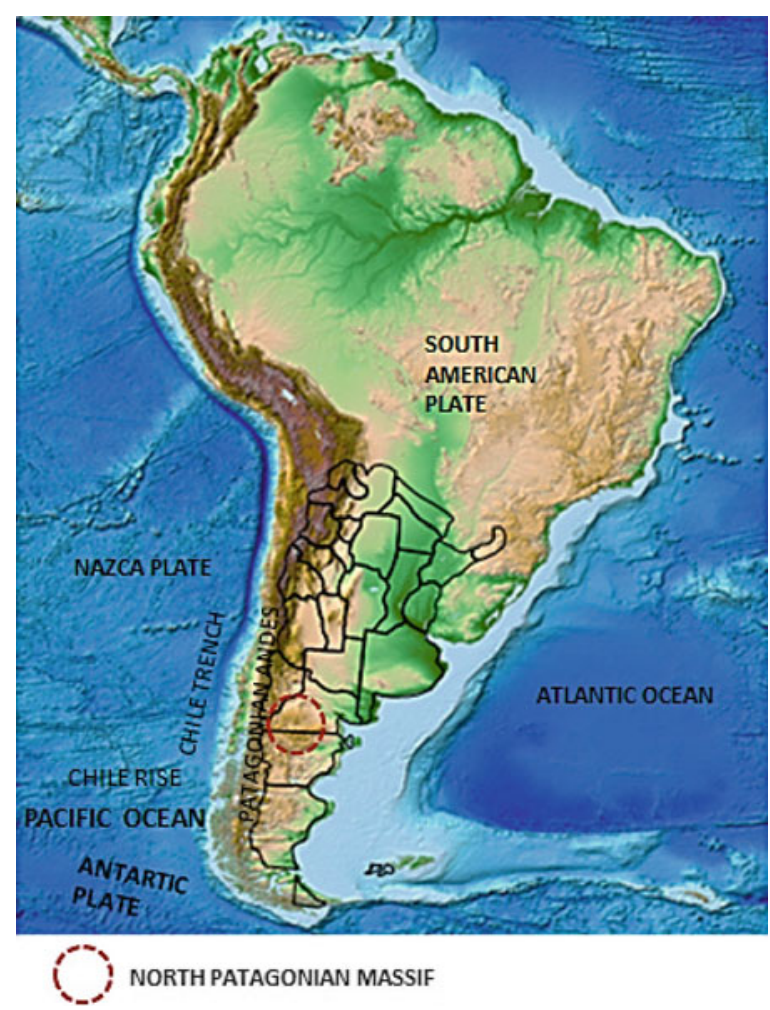

sites of Paso del Sapo and Piedra Parada, along the margins of the Río Chubut, between $42^{\circ} 30^{\prime}$ and $42^{\circ} 45^{\prime}$ south latitude and $70^{\circ} 00^{\prime}$ and $70^{\circ} 45^{\prime}$ west longitude, respectively; and (c) the western portion of the Massif, which has been marginally affected by the Andean tectonics.

\section{Methodology}

The analysis of the paleosurface was done using field data, superposition of geological and geomorphological maps and topographic profiles, aerial photographs, digital elevation models, satellite imagery, and petrographic analysis of thin sections.

\section{Regional Geological Framework}

The crystalline basement of the Northern Patagonian Massif is formed by metamorphic rocks and syntectonic granitoid rocks, extending from the Late Precambrian to the Early Paleozoic. In the eastern portion of the Massif, marine deposits are 
overlying these rocks in angular unconformity, in an environment of clastic marine platform of Silurian to Early Devonian age. The basement is intruded by granitic plutons of the Gondwana cycle, that is, from the Late Paleozoic to the Early Triassic. These plutons are overlain by ignimbritic-tuffaceous complexes belonging to the same cycle and whose radiometric ages extend from the Late Paleozoic to the Middle Jurassic inclusive (Llambías and Rapela 1984).

These are two superimposed magmatic cycles. The first one is formed solely by rocks of plutonic nature and of Carboniferous age. The second is composed of eruptive volcanic rocks, both lavas and ignimbrite flows, which formed an extensive ignimbrite plateau of Neopaleozoic to Late Triassic-Early Jurassic age. This latter event is associated with Early Jurassic plutonic processes of extensional nature (Rapela and Alonso 1991).

The crystalline basement formed a positive area at least during the Triassic and perhaps even before. This positive region was covered by fossil flora bearing sedimentary rocks, which occupied the periphery of the craton. The Jurassic sediments developed in continental environments with pyroclastic participation were covered by continental deposits of Early to latest Cretaceous age and even from the Tertiary, in which it is possible to identify the marine transgressions of the MaastrichtianDanian, Eocene, and Neogene (Miocene), respectively. A transgression from the Pacific Ocean has been recorded in a small portion of the western slope of the Massif, bearing Early Cretaceous marine sedimentary rocks.

The Northern Patagonian Massif then became a sub-positive element, which divided towards the north and south two important depositional centers starting in the Early Cretaceous: the Neuquén Group Basin and the Chubut Group Basin, respectively. Overlying the Massif rocks, only a thin and scattered Cretaceous sedimentary cover proves the physical connections between both basins in those times. Another important feature of the Massif is the existence of extensive basaltic volcanism of Cenozoic age. It started feebly during the Eocene, to continue with prominent alkaline basalt flows during the Oligocene that covered most of the Massif surface, particularly in the Meseta (or high-plain) de Somuncurá.

The Massif is characterized by the development of basaltic plateau flows and alkaline and per alkaline rocks coming from a reduced number of eruption centers. This cratonic unit is related to a tractive régime, associated with an ephemeral hot spot, located in the extra-Andean region and connected to a process of crustal thinning which, in just a few millions of years, gushed out large volumes of basalts (Kay et al. 1993).

The volcanic activity developed later on with important alkaline-acid events. The Miocene basaltic volcanism is restricted to the western portion, whereas the most modern flows occur in peripheral positions of the Massif (Ramos 1999).

The Tertiary continental deposits are interfingered with the basaltic volcanism, achieving only a modest thickness. Their development in the Massif is poor; meanwhile, through this whole period, the Massif behaved as a relatively stable, positive cratonic unit. The Quaternary deposits are represented by fluvial and piedmont deposits, with limited glacial activity along the western margin. 
The structure of the Massif is characterized by large-block tectonics, in its eastern half controlled by the extensional régime related to the opening of the South Atlantic Ocean and to the north with the development of the aulacogen basin of the ColoradoNegro rivers. The basement blocks defined tilted semi-graben systems, some of them with oblique development referred to the margin of the craton, and controlled by ancient structures (Cicciarelli 1989).

In the tectonic evolution during the Middle to Late Triassic in the north-central sector of the Northern Patagonian Massif, a marked transcurrent tectonic activity of dextral faults of east-west strike and kilometer-scale displacements is documented (Giacosa et al. 2007). The faults affect the Early Paleozoic metasediments, the Gondwana granitoids, and the rocks of the Los Menucos Complex, in a similar manner.

The present configuration of the regional structure is a consequence of the Famatinan, Gondwanan, and Patagonian orogenies and, to a lesser degree, the Andean orogeny, with the development of basement blocks, tilted by compression and transpression with dominance of northwest-oriented fracturing (Ramos and Cortés 1984).

During the Andean cycle, a minor tectonic inversion took place in the western sector of this geological province, and ancient alignments of northwestern strike were reactivated in the central and eastern areas. The effects of this orogeny have been feeble and, in some portions, even absent.

\section{Paleoclimates}

Paleontological evidence indicates that during the Mesozoic, the climate of the region was warm to hot and humid. From the paleo-floristic point of view, no plants are known in the Middle to Late Paleozoic, whereas in those formations attributed to the Mesozoic, the paleo-flora is important due to the existence of rich Triassic and some Jurassic tapho-floras (Arrondo et al. 1984). Likewise, paleo-palynological records of great biodiversity reflect abundant plant life which characterized the Northern Patagonian region during the Mesozoic (Volkheimer 1984). Concerning the Cenozoic fossil floras, the groups of tapho-floras studied by Romero and Dibbern (1984) are indicators of gradual changes in the environmental conditions, from a temperate-hot and very humid climate to a cooler and drier one. The microfloristic associations that occurred in the Late Eocene-Early Oligocene suggest that there were areas localized in lower topographic sites with humid climate and protected environments, as well as others corresponding to conditions of higher and drier sites of undulating relief, exposed to maritime wind régimes with abundant seasonal rainfall (Pothe de Baldis 1984).

Studies of mixed paleo-floras during the Cenozoic of Chile and Argentina suggest that their development took place under relatively warm temperatures and high annual rainfall, with little seasonal variability (Hinojosa and Villagrán 2005). 


\section{Landscape Evolution}

To understand the genesis of the landscape features and its physical pattern on a long time scale, the period between the end of the Paleozoic and the entire Mesozoic is taken into consideration. This very long period is coincident with a global change in the Earth tectonic régime, moving from compressive conditions to the initiation of the Mesozoic distension.

A fundamental importance is attributed to the role of the climatic and tectonic controlling factors and also to the analysis of weathering profiles which may be considered as firm bases on which the study of the long-term development of these landscape. Specific key factors determining the conditions in which these landforms were generated are herein analyzed.

The model of landscape evolution used in this chapter is that proposed by Wayland (1934), who coined the term "etchplanation" and explained its meaning. When the alteration material is eroded by fluvial action, the weathering front is exposed as an "etchplain" (Wayland 1934), named by other authors as a "chemical corrosion plain" (Twidale 1982, 1985, 1987, 1989, 1990; Vidal Romaní 1989; Vidal Romaní and Twidale 1998). The spatial variation of the factors that determine the weathering rates of the rocks, particularly lithology, fracturing and jointing of the rocky blocks, climate, and drainage comprise important elements for this landscape evolution model. Numerous names have been proposed for the different types of etchplains. For instance, Thomas (1978) has developed a classification, taking into account the lithology and structure of the rocks, the degree of dissection, denudation of the regolith, and the detailed morphology of the weathering front.

\section{Surveying the Gondwana Paleosurface}

The Gondwana paleosurface covers a large area exceeding 20,000 sq. $\mathrm{km}$ in the study area. Its morphology is that of a plain, but no perfect planation has in fact taken place. It is actually an undulating plain, with low, rounded summits, of little local relief, which nevertheless has well-defined, drainage divides (Fig. 2a-c).

Regional geological profiles show the low-relief, topographic surface developed on top of plutonic and volcanic rocks, on which the Late Cretaceous and Paleogene/Neogene sedimentary rocks overlie in total concordance. Younger units are also the bedrock for the development of younger planation surfaces (Aguilera 2006a, b, 2007; Aguilera and Rabassa 2010) (Fig. 3).

In the central-northern portion of the Massif, the smoothly undulating landscape is monotonous, with flat sections and sporadic rounded hills, whereas in the western area, a low hill relief is present with a few higher crests.

In the western area, next to the Limay and Collón Curá rivers, close to latitudes $40^{\circ} 00^{\prime}$ to $40^{\circ} 45^{\prime} \mathrm{S}$, low-range profiles are defined. The paleosurface is noted for its smooth topography, composed of hills of concordant summits and isolated 
a

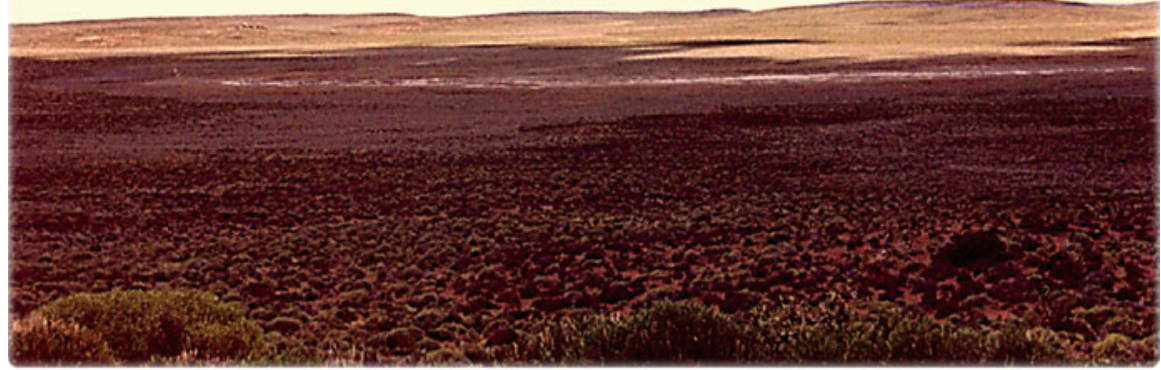

b

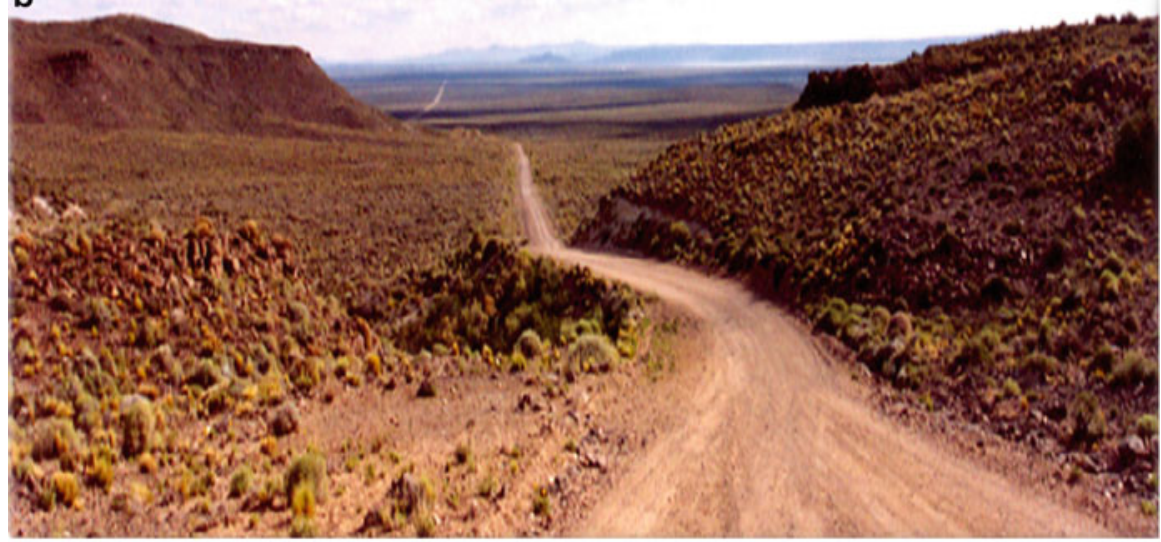

c

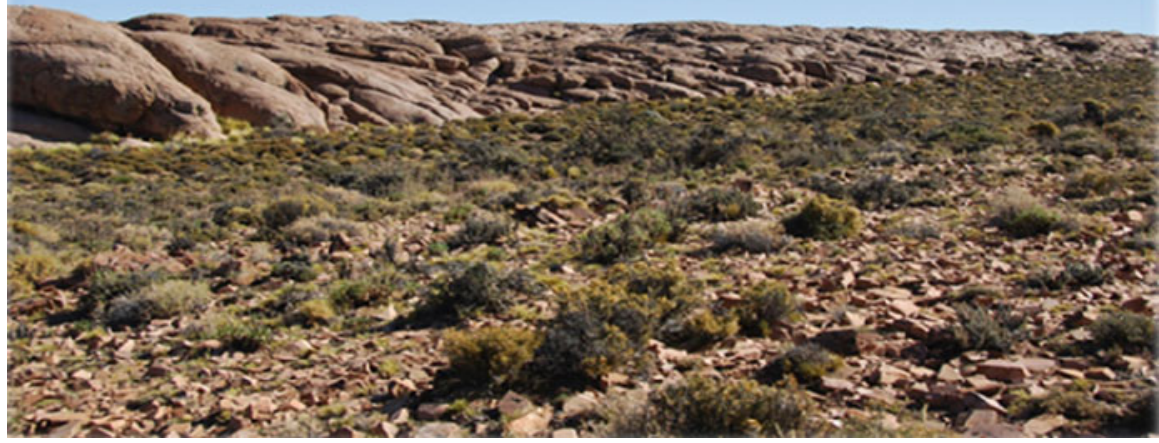

Fig. 2 (a) Panoramic view of the planation surface, in the way to Laguna Blanca, (b) Panoramic view of the planation surface. In the foreground, remnants of the Cretaceous sedimentary rocks. The road follows the planation surface. At the background, the Sierra de Quepuniyeu, (c) Panoramic view of the planation surface. Rounded landforms limited by an orthogonal fracture network may be observed. Note the absolute flatness of the paleosurface 

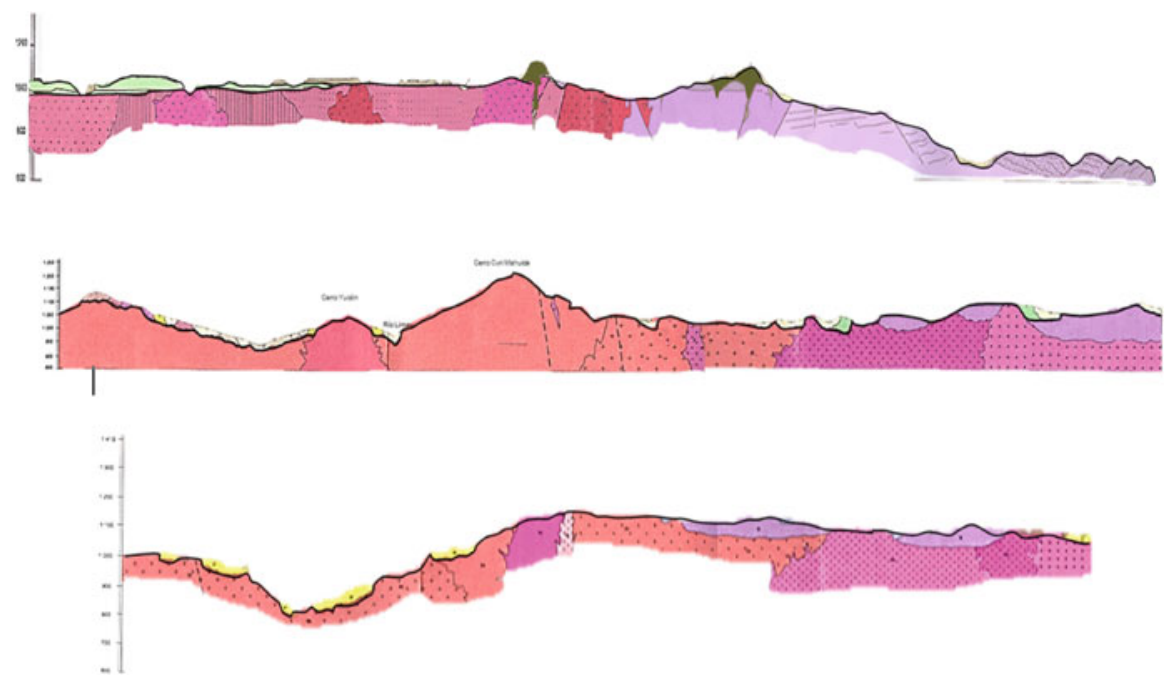

Fig. 3 Geological sections showing the planation surface cutting across diverse geological structures. Regionally, the surface is essentially flat, in spite of a few local topographic expressions (Source: SEGEMAR, Geological Sheets 4169-I and 4169-II). In reddish colors, plutonic rocks; in violet, purple, and pinkish tones, volcanic rocks

wetlands. In its central part, frequent small depressions are found, which during rainy seasons become temporary ponds and shallow lakes. The drainage pattern of the westernmost higher block is of the radial type, oriented towards the periphery, which is conterminous with the larger streams that have their local base level in the Río Limay.

In this portion of the Massif, the paleosurface reaches its maximum elevations over 1,250 meters above sea level (m a.s.l.). This zone would have been uplifted in a block pattern, inferring the existence of a large fault but with no erosion scarp, due to intensive fluvial erosion. The dissection degree is very marked with the development of deep valleys, favored by lines of weakness along fractures, faults, and joints. Drainage patterns of the dendritic and/or parallel types are noted for these structural controls (Fig. 4).

The few areas with a major topographic expression locally show steeper slopes. It is the case of landforms composed of convex hills, interrupted by the development of rocky crests with higher resistance to weathering and erosion (differential weathering). These crests are usually symmetrical and are partially buried by weathered materials, mostly mobilized. The granitic bodies appear segmented by faults and joints, the latter following two directions in an almost orthogonal pattern, which improve the water infiltration penetration to deeper levels. In these sectors, the maximum intensity and extension of the fragmentation and disintegration processes take place, which facilitate the decomposition of the rocks in blocks and boulders of varied sizes. Thus, residual landforms corresponding to varied lithology occur in the paleosurface, such as inselbergs, domes, castle koppies, nubbins, bornhardts, 

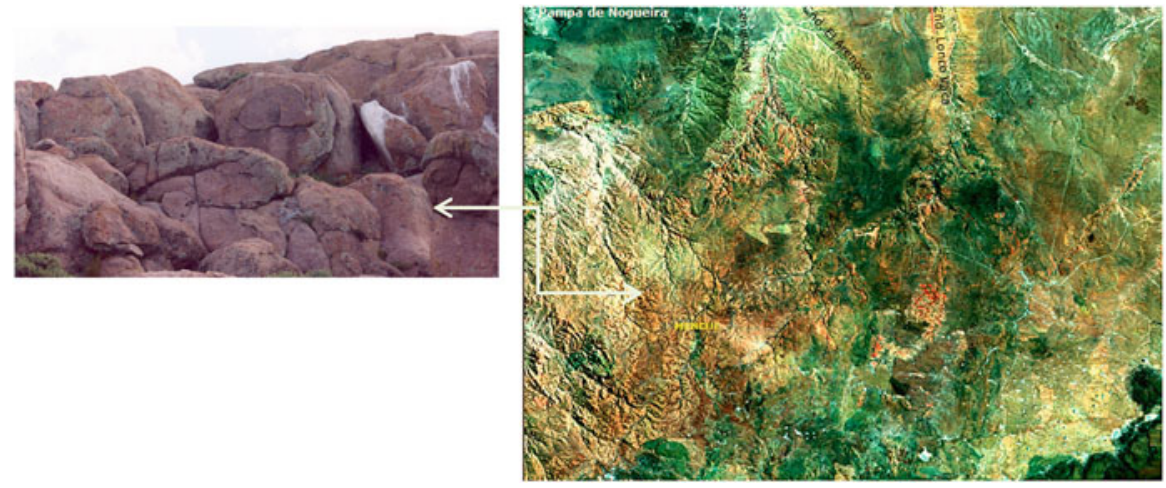

Fig. 4 In pinkish-reddish colors, the granitic rocks, over which the paleosurface is developed, may be observed, at the left side of the Landsat image 7 RGB 435. The network of darker tones due to the fracturing and the high degree of dissection is noted. In the lower right sector of the image, numerous depressions and hollows occur aligned, suggesting an ancient drainage system

and rocky crests, accompanied by middle- to small-scale landforms as blocks, balls, gnammas, taffonis, and corestones (Aguilera et al. 2010).

To the east, the Massif gradually loses altitude and the paleosurface is found at elevations of 1,000, 800 and $750 \mathrm{~m}$ a.s.l. The differential nature of the weathering and the erosion processes operate at all scales. At the level of the mineral composition, it acts in terms of mineral stability and some textural parameters, such as grain size. A slow but steady transformation of the primary to secondary minerals takes place.

At the scale of outcrops, the surface covers large areas of similar lithological composition with relatively uniform resistance to erosion. The rocks of the crystalline basement show that the patterns of joints and faults play a dominant role in differential weathering. Some sectors have been identified with an almost horizontal topography over granitic and ignimbrite lithology. In certain areas, a pattern of paleo-drainage, formed by numerous aligned depressions, may be observed (Fig. 4).

This sector, with a markedly flat landscape, appears to be interrupted in some areas by topographic landforms which generated positive and negative relief (Fig. 5). Near La Esperanza, groups of aplite and lamprophyre dykes intruded granitoid rocks. These injected masses of varied lithological composition show a larger (aplites) or lesser (lamprophyres) resistance to erosion than the bedrock, thus forming alternating highs or depressions.

In the region of Los Menucos, the homogeneity of the paleosurface is interrupted by a structural depression which is bounded by a fault system over $100 \mathrm{~km}$ long. Additionally, structural highs of dome shape are observed there, with a radialtype drainage pattern, with development of gnammas or "pias" (i.e., rock kettles; Fig. 6). 

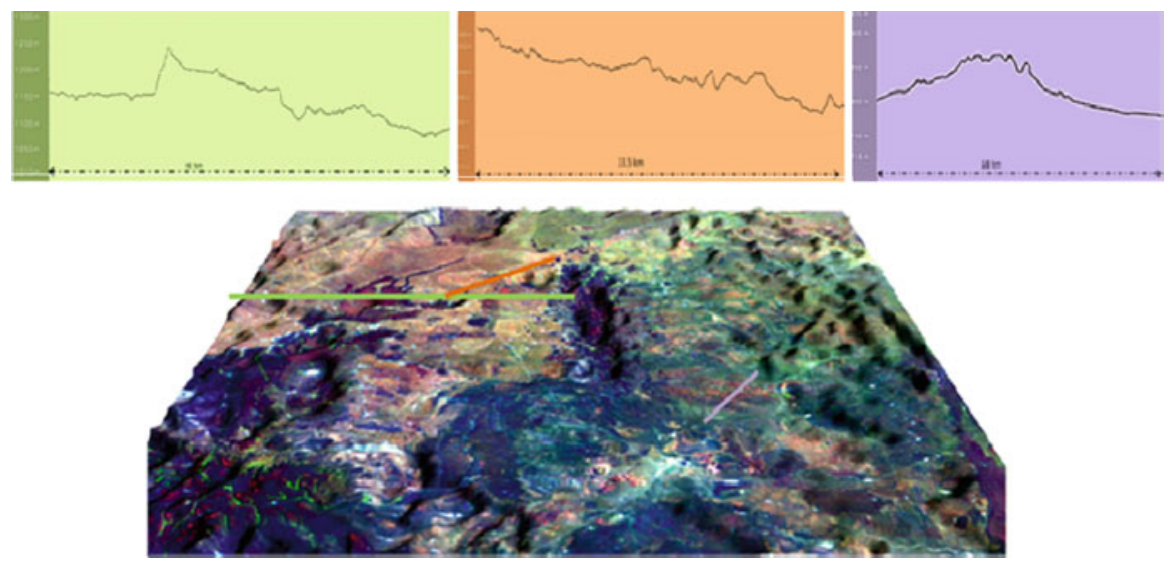

Fig. 5 Digital elevation model with superimposed satellite image Landsat 7 RGB 541. The vertical exaggeration is $\times 4$. The colored lines indicate the position of the topographic profiles shown, with no scale exaggeration, at the central sector of the Massif

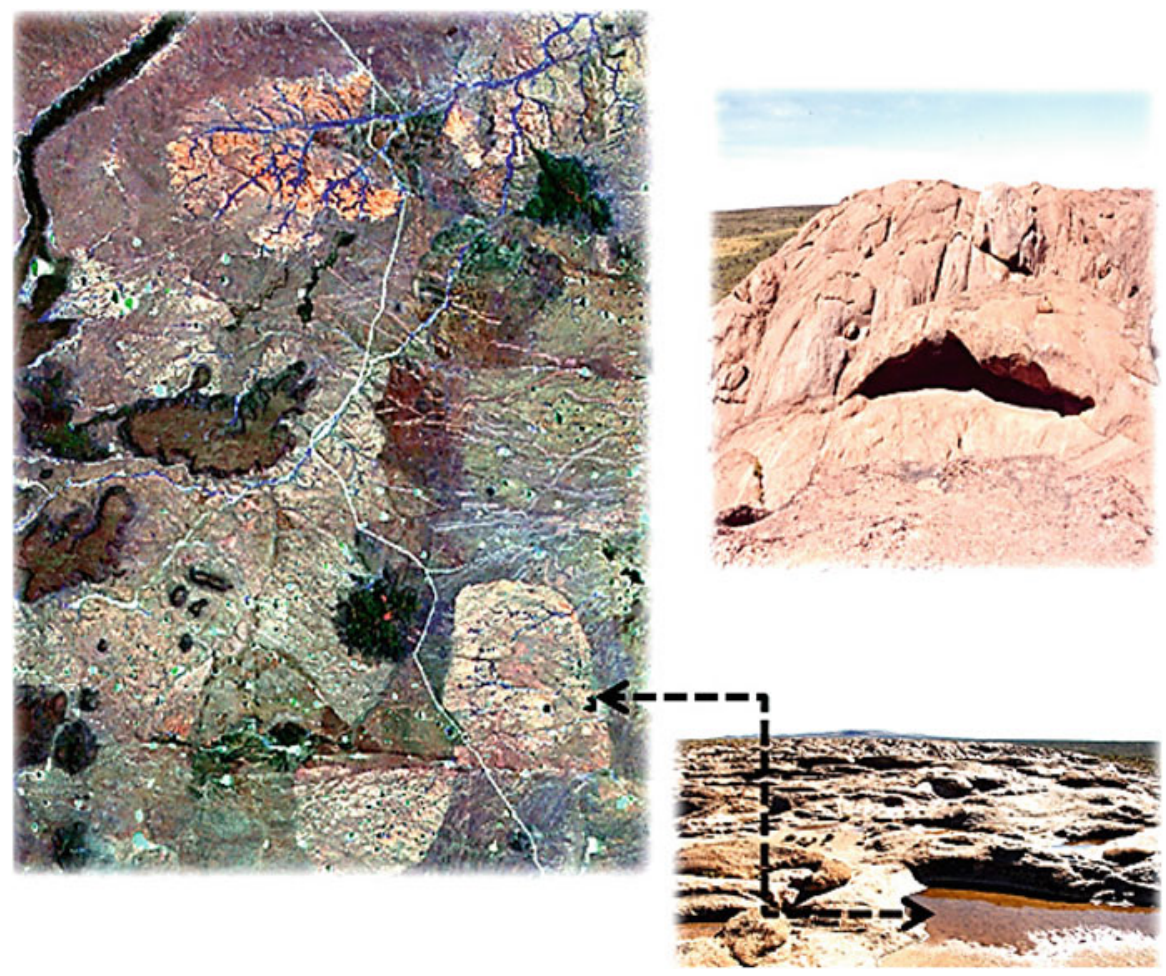

Fig. 6 La Esperanza-Los Menucos sector, satellite image Landsat 7 RGB 435. The plutonic body of the Calvo Granite has been segmented in two halves by the Loma Blanca fault. The plutonic bodies have topographic expression, with development of gnammas pias 


\section{Description of Weathering Profiles}

Some of the ancient weathering profiles, observed in the field, are described here.

(a) Weathering profile developed on plutonic rocks outcropping in the area of La Esperanza, an igneous body named as the Calvo Granite (Llambías and Rapela 1984; Llambías 2001), composed of potash feldspar, oligoclase, quartz, and biotite. The weathering impact is recognized by the reddish appearance of the rocky surface and the transformation, though in a varied degree, total or partial, of the mineral components. The observation of changes at the mineralogical level indicates that the potash feldspar has usually offered a larger resistance to weathering than plagioclase, since this has been transformed in a powdery material in which kaolinite is dominant, whereas biotite is altered to vermiculite - with the corresponding volume increase - and the mobilization of the opaque minerals. Quartz is abundant and resistant to alteration. Its grain size, from medium to coarse, makes it susceptible to alveolar erosion; therefore, the pressure exerted by expansion on each crystalline union increased with the growth of grain size (Derrau 1970). The quartz texture is granulated, hypidiomorphic, with anhedral and subhedral crystalline faces, which provides a lesser cohesion than if all crystalline faces were anhedral. Towards the upper levels of the profile, the mineralogy and primary texture of the original rock occurs obliterated by the dominance of clayey materials and iron oxide minerals. The original textures may be distinguished towards the lower zones, but there is a loss of coherence of the grains and an increase in porosity.

The upper portion of the profile is slightly disturbed by scarce roots of xerophile vegetation and slope erosion. The part immediately below does not show perturbation, and it retains structures of the original rock, "in situ" contour of dykes and unweathered corestones. It is observed that the primary minerals have not changed their composition; thus, volumetric changes are not generated. Note that iso-volumetric weathering is characteristic of saprolite.

Dykes have quartz-feldspar composition and anhedral micro-grained texture, showing high resistance to weathering. They occur in the topography as positive features, and they maintain their extent without tectonic perturbation (not mobilized, "in situ"), together with the whole granitic mass or partially altered to regolith. According to the deepening level of the profile, stripes, fringes, zones, and rounded arenization masses occur together with other areas of fresh granite. Arenization, in the sense of Derrau (1970), indicates an altered but not mobilized, granitic material, thus being a saprolite that behaves as a slightly compacted sand, and the unequal fracturing and fissuring of the material permits the persistence of unweathered corestones and shows that the bottom of the weathering profile is not totally flat (Fig. 7).

(b) A remnant of the planation surface developed upon the Jurassic volcanic rocks may be observed between the localities of Paso del Sapo and Piedra Parada, sites located along the Río Chubut valley. On such surface, a regolith mantle is preserved, a product of alteration of the underlying volcanic units, and it is overlain unconformably by the quartzitic sandstones of the Paso del Sapo Formation, of Late Cretaceous age. 


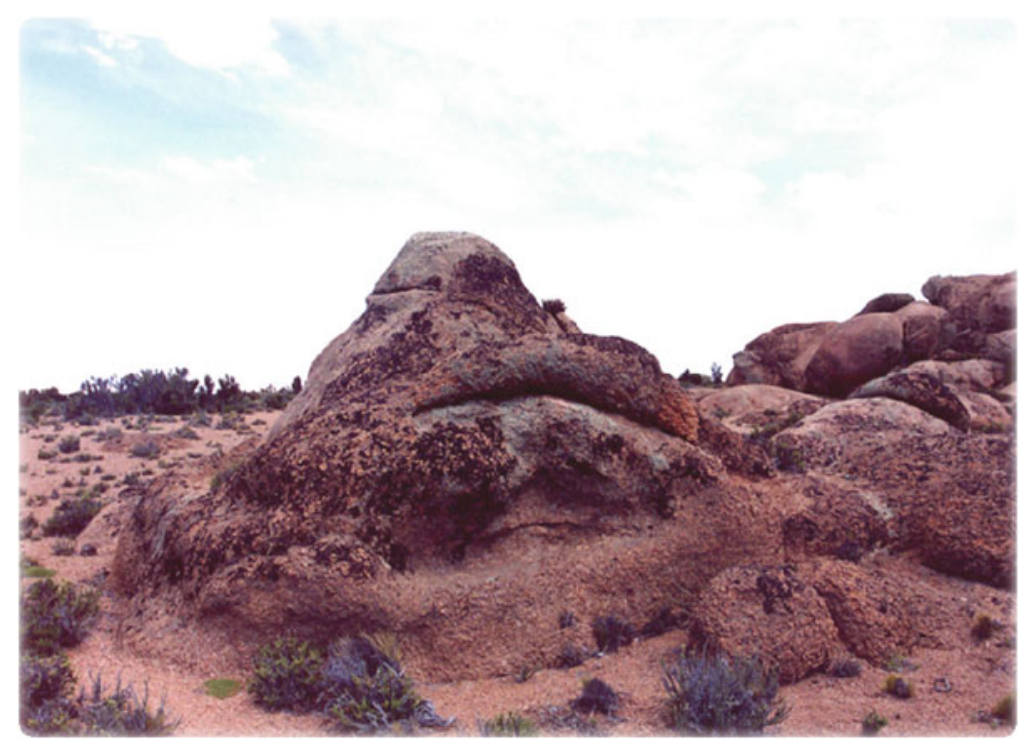

Fig. 7 Arenization in altered granitic material, not mobilized yet. The saprolite acts as slightly compacted sandstone, with uneven fracturing and fissuring of the material allows the persistency of unweathered corestones, showing that the bottom of the weathering front is not absolutely flat

A bluish-gray-colored regolith, with purple to reddish sectors, has developed over the volcanic rocks, in which a whitish mottled zone gradually evolves, as a result of transformation of plagioclase into clayey materials, mainly kaolinite. The regolith shows a clast-supported texture of approximately $1 \mathrm{~m}$ in thickness, with angular clasts of volcanic rocks and a scarce epiclastic matrix of sandstones. The clasts of andesitic rocks show whitish lumps (pseudomorphs of glomeroporphyritic texture) due to plagioclase alteration into clayey materials, basically kaolinite. This process of alteration to kaolinite generated an aggregate of pseudomorphic alteration in both the clasts and the matrix.

The horizontality of the paleosurface is observed over all the Jurassic outcrops. Towards the east the Cretaceous sediments have covered the paleosurface and fossilized its regolith, though this paleosurface is now being gradually exhumed by erosion.

At a regional scale, this planation is observed where the flat surfaces with scarce topographic expressions dominate, generating rounded landforms of the whaleback type, as the larger forms. The advance of peeling out of the surfaces and the selective atmospheric action as a function of the structural characteristics leads towards the conservation of more resistant compartments, under the shape of residual hills such as inselbergs, which survive in the landscape as erosion remnants (Fig. 8).

The areas of multiple or superimposed lava produce structural surfaces that are horizontal. Water can percolate between flows and through joints in the basalt, resulting in chemical attack and weathering. 


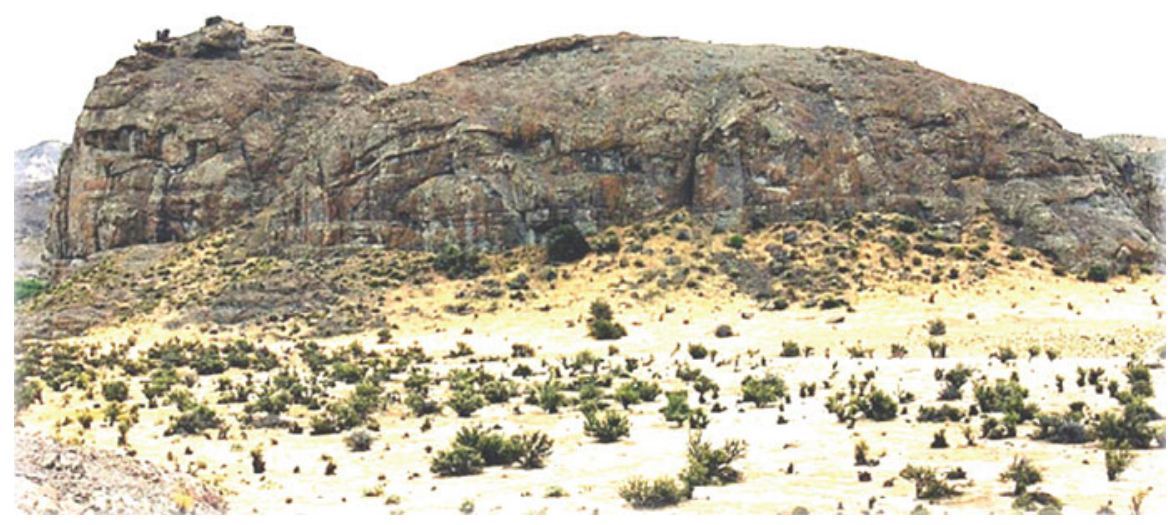

Fig. 8 Residual hills (inselbergs) stand up in the landscape as erosion remnants. The flat surfaces with scarce topographic expressions generate rounded landforms of the "whaleback" type, near Paso del Sapo

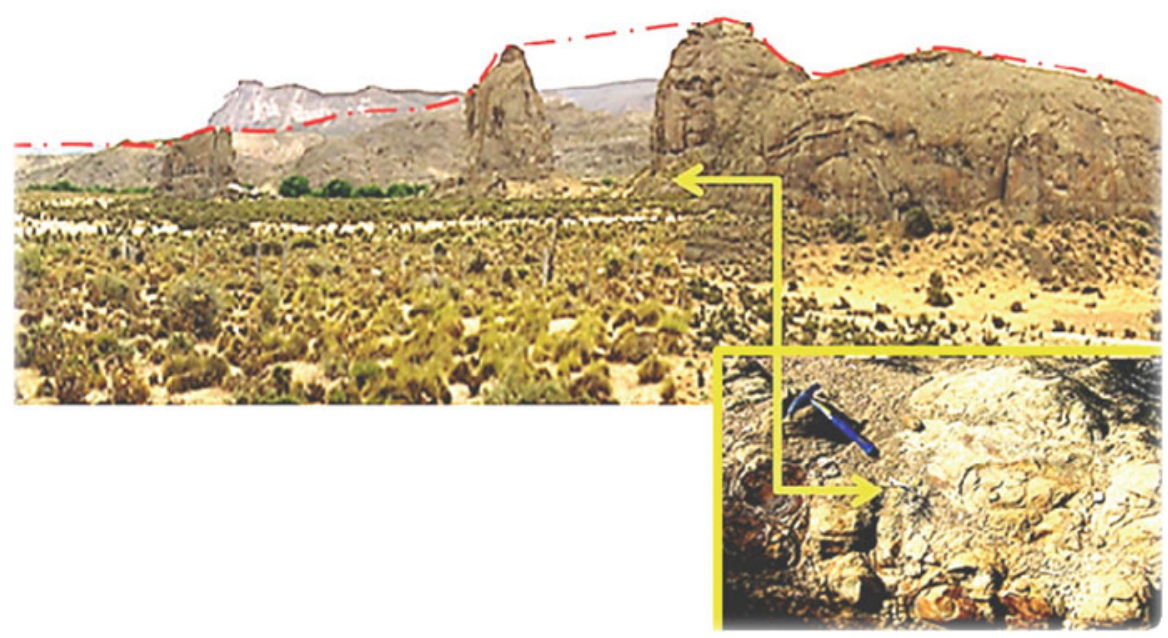

Fig. 9 Residual hills (inselbergs). The dotted red line represents the reconstruction of the paleosurface developed in Jurassic volcanic rocks. In the yellow rectangle, semicircular structures due to acting weathering processes may be observed, with rounding of their corners and a cover of loose materials of reddish color, adopting a spherical weathering type of structure

Spheroidal weathering is observed in jointed basalt. Weathering starts at the joints and works inward. As weathering proceeds, the central zone remains unaltered, with rounding of the corners producing a corestone, The corestone may be surrounded by concentric shells of partially weathered basalt producing a type of weathering structure called "spheroidal" which, according to Ollier $(1984,1991)$, would be related to element migration within the rocky mass (Fig. 9). Due to the extent of this paleosurfaces, the two phases in which these chemical corrosion 
landforms evolve, in the sense of Twidale (1989), may actually occur. Where the model of the weathering profile that takes place in underground conditions has been preserved, due to the fossilization of the regolith, the second phase concerns the denudation of the regolith and the exposure of the weathering front (Twidale 1989).

\section{General Considerations About the Stratigraphy and the Late Mesozoic and Cenozoic Paleo-geomorphology in the Western Portion of the Northern Patagonian Massif}

The western sector of the Northern Patagonian Massif in the province of Río Negro deserves a particular description, since it had a clear surface drainage direction to the west, towards the Pacific Ocean. This region has been marginally affected by the Andean tectonics, with major changes in the drainage direction which switched to the north-northeast when the Andean ranges emerged. In this area, three superposed paleo-landscapes occur, which developed sometime between the Early to Middle Cretaceous (?) and the latest Cretaceous-Paleocene, the Oligocene-Early Miocene, and the Early to Middle Pliocene. Some of the various resulting landforms have been exhumed and partially modified by the erosion agents during the Quaternary, but others have been preserved in the surface and never covered again by thick marine or continental sedimentary sequences.

The reconstruction of the paleo-landscapes has been possible thanks to several volcano-sedimentary units in terrestrial environment that had partially buried these landscapes, notably preserving the respective paleo-landforms. The oldest paleolandscape is a partially exhumed etchplain, equivalent to that described above, developed during the Early to Middle Cretaceous on the granites and metamorphic rocks of the crystalline basement (Figs. 10 and 11) and also on tilted, volcanosedimentary Triassic-Jurassic units. This etchplain was formed under tropical climate and deep chemical weathering processes. The development of the following paleo-landscape partially destroyed this Cretaceous etchplain, which was initially covered by the Late Cretaceous continental red beds of the Angostura Colorada Formation and then by the Early Tertiary sequences. The regional drainage was then in direction to the Pacific Ocean, since the Andean Cordillera had not been uplifted yet. The landscape was buried by the Late Paleocene-Eocene, volcano-sedimentary beds of the Ventana Formation (formerly known as the "Serie Andesítica"). The orogenic movements of the Late Oligocene pushed up the Patagonian Andes Cordillera, thus forcing an inversion of the drainage, now towards the Atlantic Ocean. Erosion was essentially of fluvial origin, and it entrenched a deep landscape on top of these Early Tertiary volcanic units, as well as on the etchplain developed on top of the crystalline basement and the Mesozoic sequences, the Comallo paleosurface (Fig. 12). This was a very well-integrated relief, which had reached the maturity stage (in the classical Davisian sense) when the deposition of the ignimbrites and tuffs of the Collón Curá Formation (Middle to Late Miocene) 


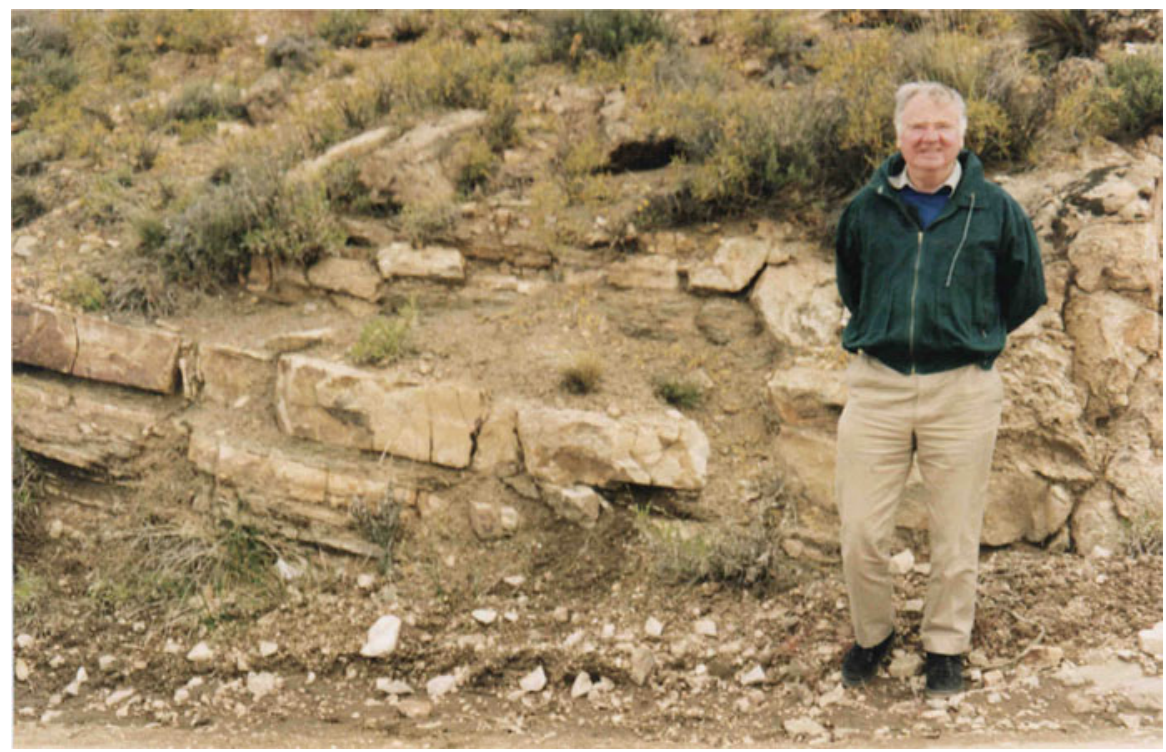

Fig. 10 Deeply weathered crystalline basement, near Comallo, western Río Negro province. Professor Cliff Ollier for scale (Photo J. Rabassa 2001)

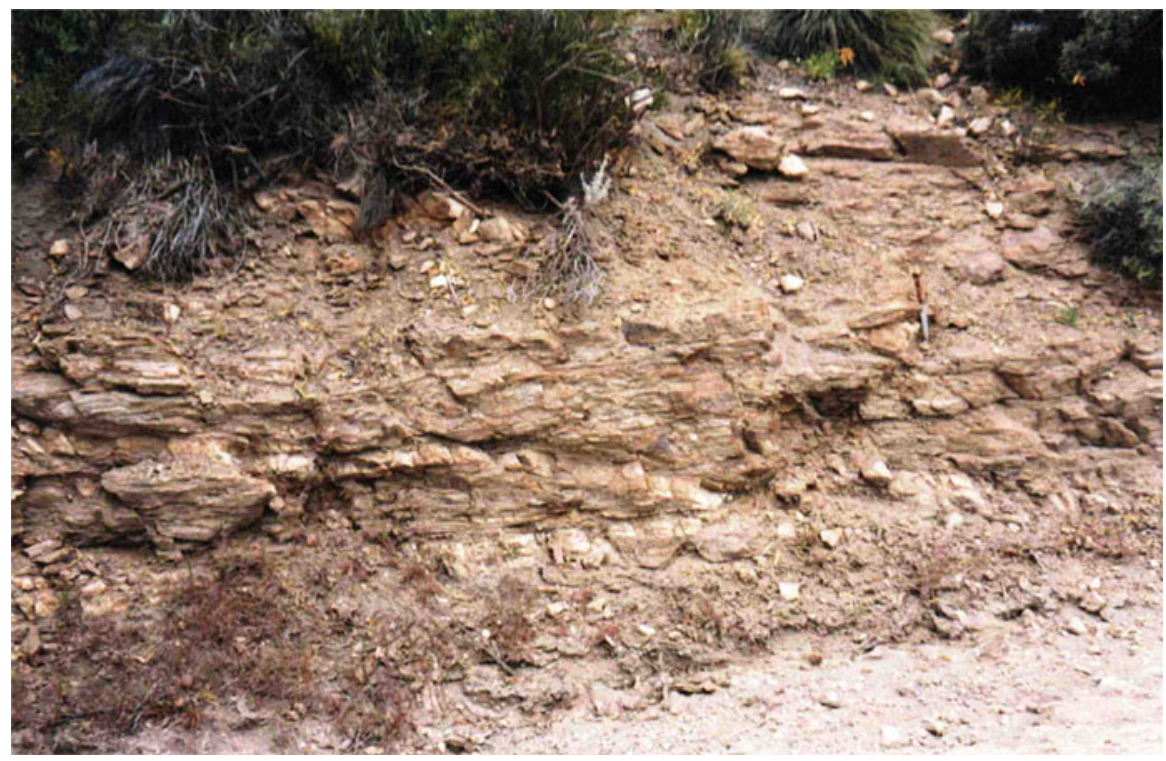

Fig. 11 Deeply weathered Paleozoic metamorphic rocks, near Comallo 


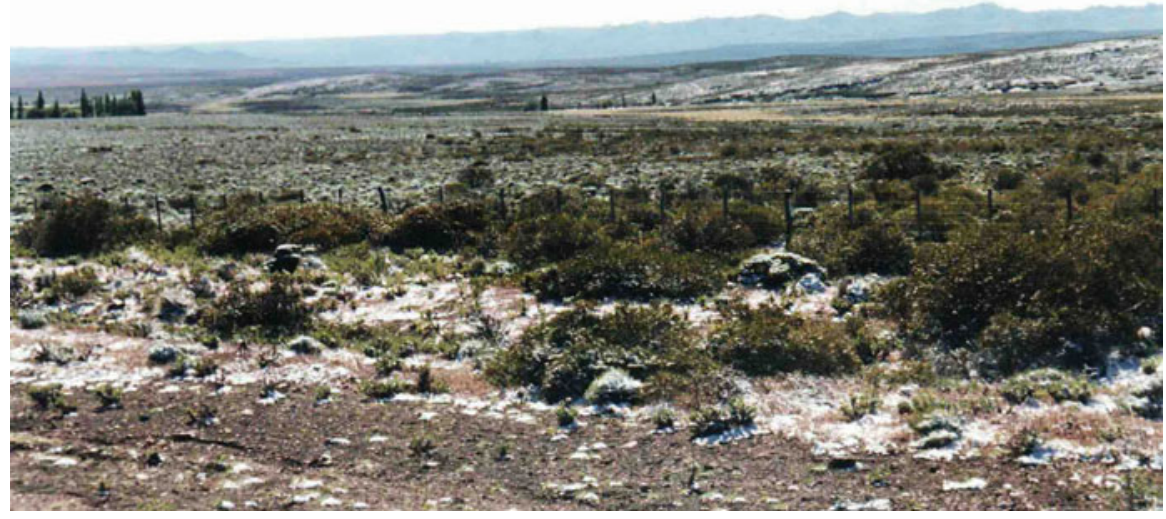

Fig. 12 In the background, the Comallo paleosurface, the Late Mesozoic etchplain that dominates the landscape of the Northern Patagonian Massif

took place. This volcanic formation rapidly buried the existing depressions, with emerging low hills as the unique positive elements of the landscape. At the MiocenePliocene boundary, new orogenic movements finally emplaced the Patagonian Andes at their present position and forced changes in the climate of the region, gradually leading to the present cold, semiarid steppes.

The information presented here is a synthesis of the basic aspects of the paleogeomorphology of the region (Rabassa 1974, 1975, 1978a), reviewed according to new concepts related to long-term landscape evolution (Rabassa et al. 2010). The study revealed abundant information about the existence of several superposed paleo-landscapes, some of them being discussed in detail below. In this chapter, it is herein analyzed the fundamental characteristics of these paleo-landscapes.

The more relevant topics of the studied region have been discussed elsewhere (papers mentioned above). The stratigraphy of the cited area has been described by Rabassa $(1975,1978 b)$, and it was compiled after extensive fieldwork over 250 sections and selected localities. Table 1 presents a summary of the identified lithostratigraphic units.

Considering the cited paleo-landscapes, the most relevant ones to the purpose of this chapter are the Cretaceous and Early Tertiary landscapes. A large portion of the ancient landscapes is still being denudated and exhumed. These ancient landscapes were eroded in several stages, which probably started in the Early to Middle Cretaceous. The area located between the localities of Pilcaniyeu Viejo and Neneo 
Table 1 Stratigraphy of the western margin of the Northern Patagonian Massif (Slightly modified from Rabassa 1974, 1975, 1978b)

\begin{tabular}{|c|c|c|c|}
\hline $\begin{array}{l}\text { Litho-stratigraphic } \\
\text { units }\end{array}$ & Lithology & Geochronological units & $\begin{array}{l}\text { Radiometric } \\
\text { ages }\end{array}$ \\
\hline$\overline{\text { Alluvium }}$ & $\begin{array}{l}\text { Alluvial and colluvial sands and } \\
\text { gravels and other sediments }\end{array}$ & Holocene & $\begin{array}{l}<10 \mathrm{ka} 14 \mathrm{C} \\
\text { BP }\end{array}$ \\
\hline $\begin{array}{l}\text { Pichi Leufu Drift } \\
\text { (Great Patagonian } \\
\text { Glaciation) }\end{array}$ & Till and other glacigenic deposits & Early Pleistocene & ca. $1 \mathrm{Ma}$ \\
\hline Piedmont deposits & Gravels and sands & Pliocene to recent & \\
\hline $\begin{array}{l}\text { Late Miocene to } \\
\text { Pleistocene } \\
\text { basalts }\end{array}$ & Basalts and scoria cones & $\begin{array}{l}\text { Late Miocene to } \\
\text { Pleistocene }\end{array}$ & $8-1.5 \mathrm{Ma}$ \\
\hline Collon Cura Fm. & $\begin{array}{l}\text { Ash-flow and ashfall tuffs, fluvial } \\
\text { sedimentary rocks }\end{array}$ & Middle to Late Miocene & $15.5-11 \mathrm{Ma}$ \\
\hline Ventana Fm. & $\begin{array}{l}\text { Basalts, trachytes, rhyolites, } \\
\text { tuffs, volcano-sedimentary } \\
\text { rocks }\end{array}$ & $\begin{array}{l}\text { Late Paleocene to } \\
\text { Eocene }\end{array}$ & $60-50 \mathrm{Ma}$ \\
\hline $\begin{array}{l}\text { Angostura Colorada } \\
\text { Fm. }\end{array}$ & $\begin{array}{l}\text { Sandstones, siltstones, and } \\
\text { mudstones, tuffs, continental } \\
\text { red beds }\end{array}$ & Late Cretaceous & \\
\hline "Comallo beds" & Volcano-sedimentary complex & Triassic to Late Jurassic & \\
\hline Crystalline basement & $\begin{array}{l}\text { Granitic, granitoid, and } \\
\text { metamorphic rocks }\end{array}$ & $\begin{array}{l}\text { Middle to Late } \\
\text { Paleozoic }\end{array}$ & \\
\hline
\end{tabular}

Rucá shows the existence of several remnants of an extended high plain, carved by fluvial erosion. It is a smoothly undulating plain with very rounded summits, which lie around 1,200-1,300 $\mathrm{m}$ a.s.l., developed on top of the crystalline basement (Fig. 13) and the faulted-tilted, Triassic-Jurassic "Comallo beds" (Fig. 14). The occurrence of these Jurassic beds provides a maximum age for this planation surface. This paleo-landform shows towards the west and southwest the evidence of erosion action along its margins. The crystalline rocks are deeply weathered, indicating an ancient weathering front. This weathering front is unconformably covered by the red beds of the Angostura Colorada Fm. (Late Cretaceous) (Fig. 15). Many small paleo-depressions were also formed, probably as irregularities in the ancient weathering front after extensive denudation. These depressions were much later filled up by the tuffaceous, volcanic, and sedimentary rocks of the Ventana Formation (Paleocene-Eocene). The reconstruction of the ancient relief indicates that these depressions, probably related to the Cretaceous weathering front, and wide, extensive fluvial valleys of low gradient were draining westwards, as the crystalline basement is gradually disappearing in this direction. The pre-Tertiary drainage towards the Pacific Ocean had been already noted by Groeber (1929, p. 66). The volcanic rocks of the Ventana Fm. extended well beyond the margins of their marine depositional basin along the shallow Pacific Ocean coast and covered the crystalline basement and the Cretaceous rocks, preserving the pre-Late Paleocene landforms. This may be clearly observed in the surroundings of the town of 


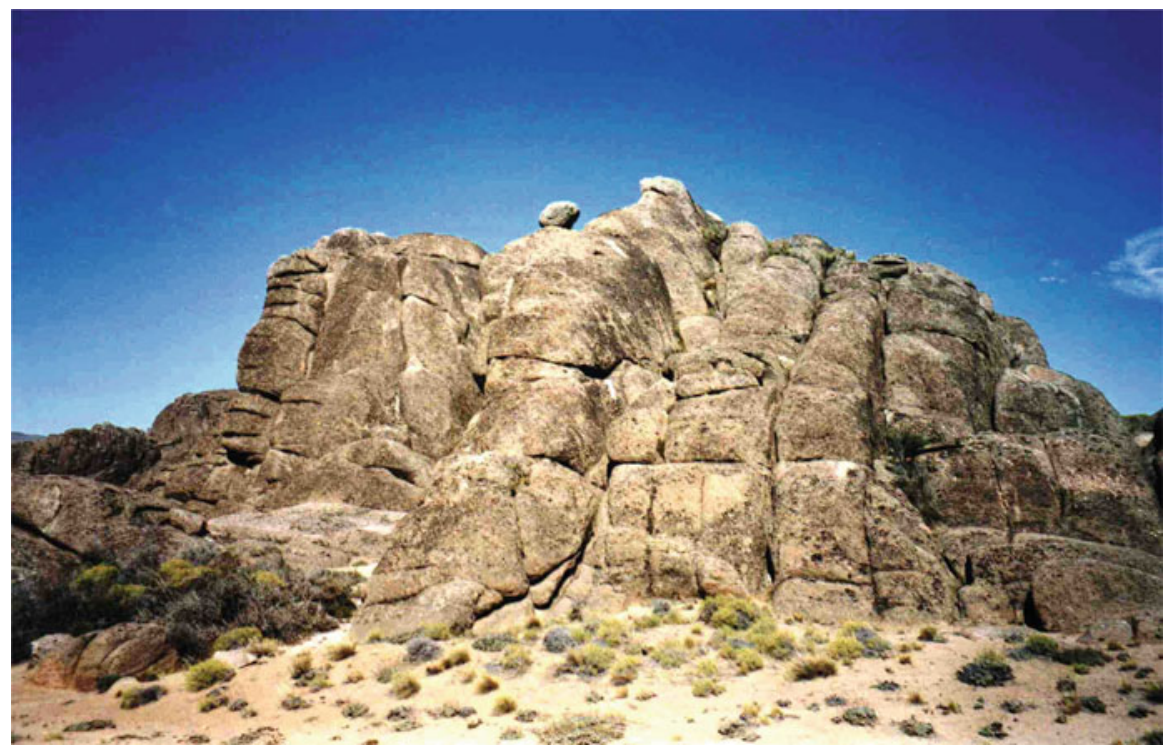

Fig. 13 Inselberg developed on Permian granites, south of Pilcaniyeu, province of Río Negro

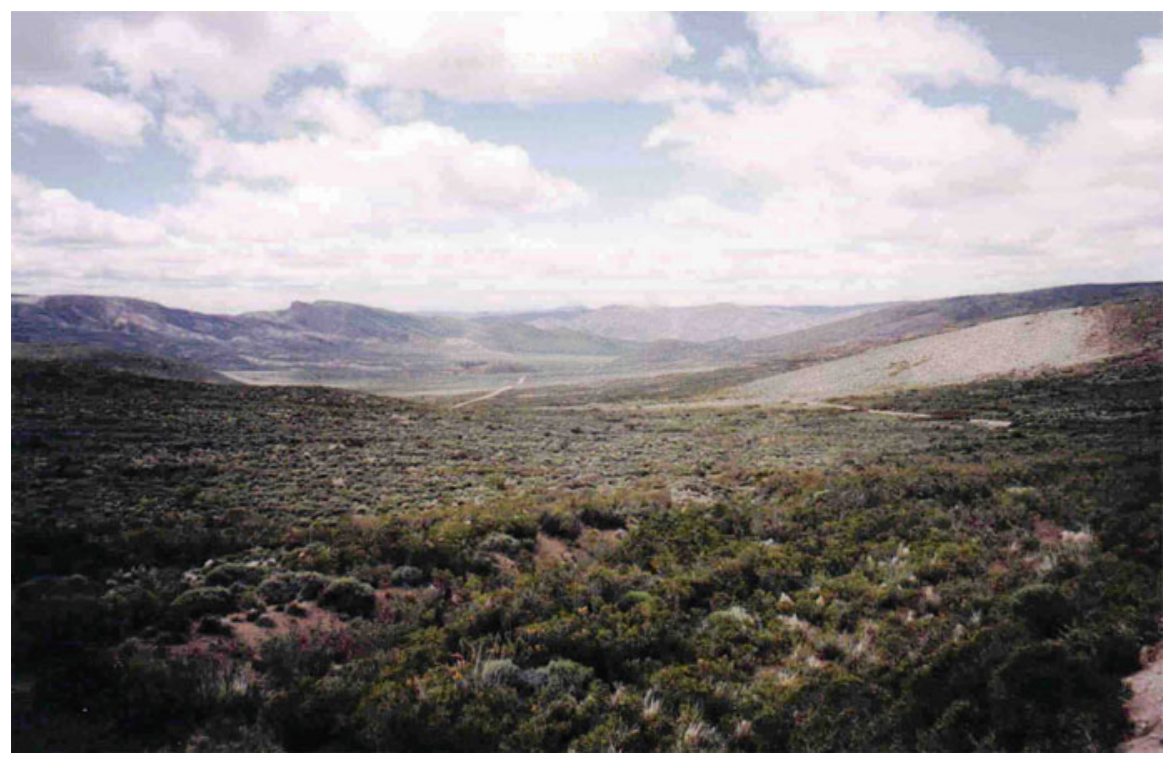

Fig. 14 The "Comallo beds" volcano-sedimentary complex (Triassic-Jurassic) exposed in the foreground. The Paleozoic granites and metamorphic rocks appear at the background. The Late Mesozoic planation surface equally cuts through all these ancient units 


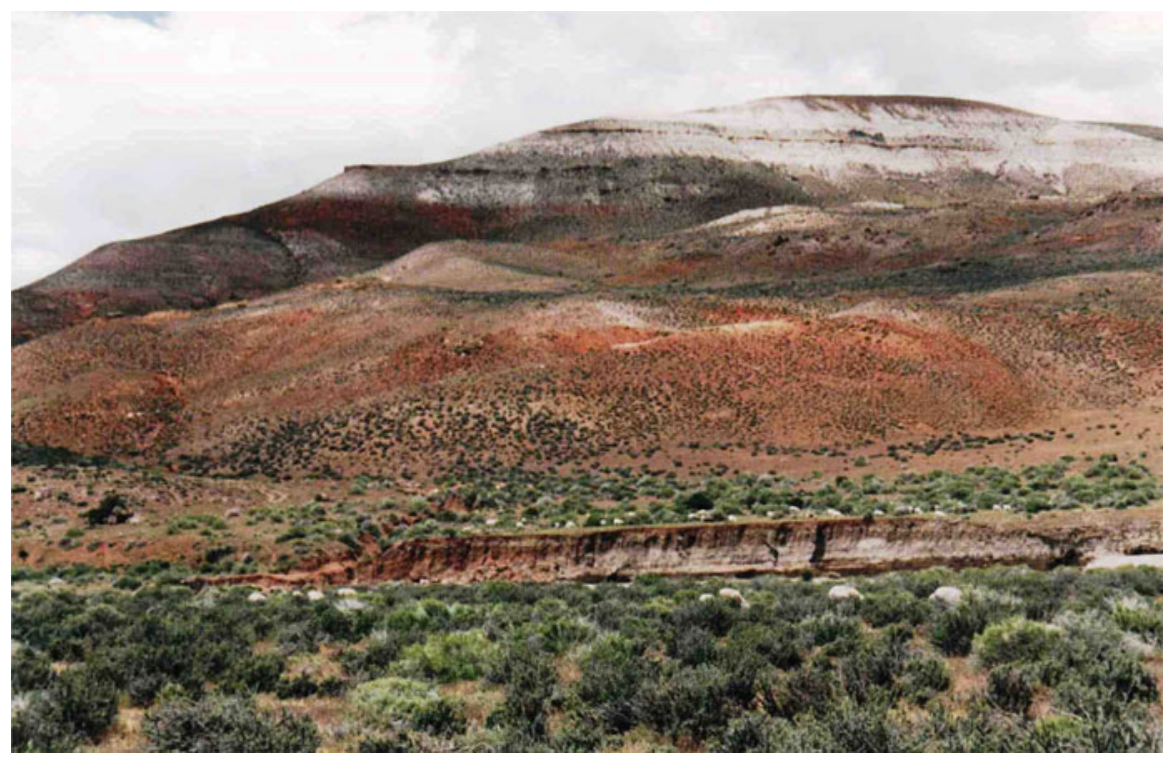

Fig. 15 Continental sedimentary rocks of the Angostura Colorada Fm., Late Cretaceous, lying on top of the Comallo paleosurface, the Late Mesozoic planation surface, probably an etchplain

Pilcaniyeu and other hills of the region, where isolated granitic and metamorphic hills have been buried by radially dipping tuffs of the Ventana Fm., presently being exhumed.

In summary, the older lithological complex integrated by the crystalline basement and the Jurassic rocks was affected by regional faulting, thus generating large uplands and depressions, which later controlled the Cenozoic landscape. The whole set was actively weathered under very warm and wet climate, which accounts for the remains of the ancient weathering front. Later, this etchplain was covered by Cretaceous sediments and partially exhumed during the Early Tertiary, with prolonged denudation of the saprolite debris and in-filling of the preexisting depressions by the Early Tertiary pyroclastic and volcanic rocks. Extensive denudation during the Late Cenozoic has exhumed the very large remnants of the ancient etchplain, presently found in the landscape.

\section{Conclusions}

Field evidence indicates that the rocky materials have been exposed to an intense and extensive erosion processes. As a consequence, a very large planation surface developed. The landforms and patterns of this landscape show, both at the small and large scales, the influence of the geological structure, generating pathways for the 
weathering processes. The interaction between a series of different climatic events over extensive time periods, the alteration processes of the rocky masses, and the erosion and transport of the regolith are responsible for the surficial morphogenesis.

The analysis of the relationship between relief, saprolite, and rock cover through time suggests that the most important factor for the differentiation of the present relief is the time of exposure of the land surface.

This paleosurface would have basically been developed in two phases. The first one would have started, though locally, to evolve in the Late Permian or Triassic, partially affecting the granitoid rocks of the Mamil Choique Formation (Early Permian), the Los Menucos Group of Late Triassic age, and the dioritoid bodies of the middle Jurassic. This period corresponds to the start of weathering attack by atmospheric action, in which the exposed rock was transformed and disaggregated, a process that developed an important alteration mantle, which buried the fresh rock under its own saprolite. The weathering was directly dependent upon the climatic conditions. Paleoclimatic studies reveal that the climate during the latest Paleozoic and the Mesozoic was very appropriate for the alteration of the granitic masses, due to very high temperature and moisture. These two factors are key issues in these processes, and the planation process culminates in the Late Mesozoic, a period almost $100 \mathrm{Ma}$ long, from the Early Jurassic to the Early Cretaceous.

Finally, a period of remobilization occurred, and the surface was exposed by denudation of the regolith. The most plausible explanation for the mobilization of the regolith would be a crustal uplifting produced during the Andean tectonics, where the Tertiary tectonics would have elevated the base level and reactivated the erosion processes.

As this surface is not totally flat, but presenting instead irregularities of a varied degree, the alteration material has not been entirely removed, but still persists in the landscape, which contains altered and fresher rocks, separated by the weathering front.

Thus, the origin of this paleosurface is attributed to deep chemical weathering, with later removal of the regolith, producing an etchplain (Wayland 1934).

The precisely determined age of these elements of ancient landscapes and their stratigraphic position reinforce the hypothesis that a large part of the Northern Patagonia Massif was a positive element of the landscape for a very long time. Due to the action of different erosion agents, including deep weathering, the paleosurface has persisted with little change over very extensive time periods. The characteristics of these ancient landscapes are not compatible with models proposed for the evolution of the Patagonian landscape that start from the uplift of the Andean Cordillera. It is necessary to extend the time scale needed for the genesis of this landscape and provide a new model for the evolution of the ancient landscape of the North Patagonian Massif. The chronology of the series of events that this model implies clearly widens our understanding of the present landscape and puts it in the context of global tectonics and possibly enables correlation with planation surfaces in other continents. 
Acknowledgments The authors want to express their deepest gratitude to Professor Cliff Ollier for his valued comments and observations, both in the field in 2001 and on a preliminary version of this manuscript.

\section{References}

Aguilera EY (2006a) Identificación y distribución de distintas superficies geomorfológicas de escaso relieve local, por medio de sensores remotos en el área del Macizo Nordpatagónico, Provincia de Río Negro. Unpublished doctoral Thesis, Facultad de Ciencias Naturales y Museo de La Plata, Universidad Nacional de La Plata, Argentina, $285 \mathrm{pp}$

Aguilera EY (2006b) Superficie de planación Gondwánica en el Macizo Nordpatagónico. III Congreso Argentino de Cuaternario y Geomorfología, Abstracts, Córdoba, Argentina

Aguilera EY (2007) Teledetección y SIG aplicados a la regionalización geomorfológica en el Macizo Nordpatagónico. In: SIMPÓSIO BRASILEIRO DE SENSORIAMENTO REMOTO, 13, (SBSR), 2007, Florianópolis. Anais. São José dos Campos, INPE, pp 1935-1942. CD-ROM, On-line. ISBN 978-85-17-00031-7

Aguilera EY, Rabassa J (2010) Origin of the Northern Patagonian Massif regional paleosurface. Geociências 29(4):467-478. São Paulo, UNESP

Aguilera EY, Aragón E, Carretero S (2010) The paleosurface on the Paso del Sapo volcanic rocks, Chubut, Argentina. Geociências 29:479-486. São Paulo, UNESP, Brazil

Aragón E, Carroll AR, Aguilera EY, Cavarozzi CE (2005) Ancient Gondwana landforms in Patagonia. Gondwana, 12, "Geological and Biological Heritage of Gondwana" Abstracts, Academia Nacional de Ciencias, Mendoza, p 46

Arrondo OG, Artabe AE, Morel EM, Petriella B (1984) Floras fósiles Mesozoicas. IX Congreso Geológico Argentino (San Carlos de Bariloche). Relatorio 2(1):367-372

Cicciarelli MI (1989) Análisis estructural del sector oriental del Macizo Nordpatagónico y su significado metalogénico. Unpublished doctoral thesis, Facultad de Ciencias Naturales y Museo de La Plata, Universidad Nacional de La Plata, Argentina, 179 pp

Derrau M (1970) Geomorfología. Editorial Ariel, Barcelona, 442 pp

Giacosa R, Lema H, Bosteros A, Zubia M, Cucchi R, Di Tomasso (2007) Estructura del Triásico de la región norte del Macizo Nordpatagónico $\left(40^{\circ}-41^{\circ} \mathrm{S}, 67^{\circ} 30^{\prime}-69^{\circ} 45^{\prime} \mathrm{O}\right)$, Río Negro. Revista Asociación Geológica Argentina [online] 62(3):355-365. ISSN 1851-8249

Groeber PF (1929) Líneas fundamentales de la geología del Neuquén, Dir. Gral. Minas, Geol., Hidrol., Buenos Aires, Publ. 58. Min. de agric. de la Nación, Buenos Aires

Hinojosa LF, Villagrán C (2005) Did South American Mixed Paleofloras evolve under thermal equability or in the absence of an effective Andean barrier during the Cenozoic? Palaeogeogr Palaeoclimatol Palaeoecol 217(1-2):1-23

Kay SM, Ardolino A, Franchi M, Ramos V (1993) Origen de la Meseta de Somún Cura: distribución y geoquímica de sus rocas volcánicas máficas. $12^{\circ}$ Congreso Geológico Argentino and $2^{\circ}$ Congreso de Exploración de Hidrocarburos, Actas, 4, pp 236-248

Llambías EJ (2001) Geología de los Cuerpos Ígneos. In: Serie de Correlación Geológica 15, Instituto Superior de Correlación Geológica, INSUGEO, San Miguel de Tucumán, 232 pp

Llambías EJ, Rapela CW (1984) Geología de los complejos eruptivos de La Esperanza, provincia de Río Negro. Revista de la Asociación Geológica Argentina 39(3-4):220-243

Ollier C (1984) Weathering, 2nd edn. Longman, Essex

Ollier CD (1991) Ancient landforms. Belhaven, London

Pothe de Baldis ED (1984) Microfloras fósiles Mesozoicas. $9^{\circ}$ Congreso Geológico Argentino (San Carlos de Bariloche). Relatorio 2(4):393-411

Rabassa J (1974) Geología superficial en la región de Pilcaniyeu-Comallo, provincia de Río Negro. Unpublished doctoral thesis, Universidad Nacional de La Plata 
Rabassa J (1975) Geología de la región de Pilcaniyeu-Comallo, provincia de Río Negro, Argentina. Fundación Bariloche, Publicaciones del Departamento de Recursos Naturales y Energía, N $^{\circ} 17$, San Carlos de Bariloche

Rabassa J (1978a) Paleorrelieves cenozoicos en la región de Pilcaniyeu-Comallo, provincia de Río Negro, Argentina. Actas $7^{\circ}$ Congreso Geológico Argentino, Neuquén, pp 77-87

Rabassa J (1978b) Estratigrafía de la región de Pilcaniyeu-Comallo, provincia de Río Negro, Argentina. Actas $7^{\circ}$ Congreso Geológico Argentino, Neuquén

Rabassa J, Carignano C, Cioccale M (2010) Gondwana paleolandscapes of Argentina: an introduction. Geociências 29(4):439-466. São Paulo, UNESP

Rabassa J, Carignano C, Cioccale M (2014) A general overview of Gondwana landscapes in Argentina. In: Rabassa J, Ollier C (eds) Gondwana landscapes in southern South America. Springer, Dordrecht, pp 201-245

Ramos V (1999) Las Provincias Geológicas del Territorio Argentino. Instituto de Geología y Recursos Minerales. Geología Argentina. Anales 29(3):41-96. Buenos Aires

Ramos V, Cortés JM (1984) Estructura e interpretación tectónica. IX Congreso Geológico Argentino (San Carlos de Bariloche). Relatorio 1(12):317-346

Rapela CW, Alonso G (1991) Composición litológica y geoquímica del batolito de la Patagonia central. VI Congreso Geológico Chileno, Actas, 1, Viña del Mar, pp 236-240

Romero EJ, Dibbern MC (1984) Floras fósiles Cenozoicas. $9^{\circ}$ Congreso Geológico Argentino (San Carlos de Bariloche). Relatorio 2(2):373-382

Thomas MF (1978) The study of inselbergs. Zeitschrift für Geomorphologie. N. F., Suppl. Bd. 31:1-41. Berlin

Twidale CR (1982) Granite landforms. Elsevier, Amsterdam. Pub. Com, 372 p

Twidale CR (1985) Old land surfaces and their implications for models of landscape evolution. Revue Géomorphologie Dynamique 34:131-147

Twidale CR (1987) Etch and intracutaneous forms and their implications. Aust J Earth Sci 34: $367-386$

Twidale CR (1989) La iniciación subsuperficial de las formas graníticas y sus implicaciones en las teorías generales de la evolución del paisaje. Cuadernos Laboratorio Xeologico de Laxe, 13, Coruña, Spain, pp 49-68

Twidale CR (1990) The origin and implications of some erosional landforms. J Geol 98:343-364

Vidal Romaní JR (1989) Granite geomorphology in Galicia, (NW Spain). Cuadernos Laboratio Xeologico de Laxe, 13, Coruña, Spain, pp 89-163

Vidal Romaní JR, Twidale CR (1998) Formas y paisajes graníticos. Universidade da Coruña, A Coruña, Spain, $411 \mathrm{pp}$

Volkheimer W (1984) Microfloras fósiles Mesozoicas. IX Congreso Geológico Argentino (San Carlos de Bariloche). Relatorio 2(3):383-391

Wayland EJ (1934) Peneplains and some erosional platforms, Geological survey of Uganda, Annual report and bulletin. Protectorate of Uganda Geological Survey, Department of Mines, Kampala, pp 77-79 